\title{
The Effect of Digital Storytelling on Kindergarten Pupils' Achievement in Moral Instruction in Basic Schools in Oyo State.
}

\author{
Lawani Lucy Abiola, Ph.D \\ School of Education National Open University of Nigeria Lagos.
}

\begin{abstract}
Stories provide entertainment and convey information that educates receivers on moral issues and values that endure and benefit generations of different societies. Hence, there is need to expose kids in basic classes to teaching strategy in which they will need to pay attention to relevant elements in the learning environment; to store and transform information in memory. But the strategy has not been adopted in the teaching of kindergarten pupils. This study, determined the effect of digital storytelling on kindergarten pupils' achievement in moral instruction in basic schools in Oyo state.

The pre-test, post test, control group, quasi-experimental design with $2 \times 2 \times 2$ factorial matrix was adopted. 387 kindergarten pupils from nine Basic schools in Oyo State were used for the study. Five instruments used were: Classroom Observation (CO), Kindergaten Achievement Test on Moral Instruction; Digital story package; Teachers Guide on Digital Storytelling Strategy (TGDSS); Teachers Guide on Conventional Strategy (TGCS). Two null hypotheses were tested at 0.05 level of significance. Data collected were analysed using ANCOVA. There was a significant main effect of Treatment groups on students' Achievement in Moral Instruction. $(F(1,385)=29.397, P<.05)$. Pupils in the Digital storytelling group had higher adjusted post test achievement $(\bar{x}=9.73)$, with the control group trailing behind $(\bar{x}=4.293)$. Digital storytelling handed down to kids the experiences, exploits, customs, traditions and cultures through stories that are considered before making decisions.
\end{abstract}

Keywords: Digital Storytelling, Conventional, Gender, Kindergarten pupils.

\section{Introduction}

Stories are passed from one generation to another generation by word of mouth. Our ancestors and fore-fathers handed down to us their experiences, exploits, customs, traditions and cultures through stories that are considered before making decisions. Story telling is traditional and predates the ancient Greek period of developing the act of writing on slates around 70 B.C. The use of stories in education is natural and it cuts across races, nations, religion and beliefs. In recent times apart from the learning experiences in storytelling, it is a methodology for teaching and for providing education for learners at all levels of studies.

The powers of stories are recognized for centuries. Prior to the advent of formal education, stories were used as natural mode of thinking and education. There were family histories and many fairy tales, so much so that researchers informed that all knowledge comes from stories (Barret, 2005). Using stories in the classroom is found to be of great importance to child development. The use of oral histories in classroom is an important tool and aid in learning. When children listen to stories, their imaginations are enriched and stimulated; telling stories to children increase their vocabulary and they learn about the cultural values and mores in their societies. Fairy tales teach children on a very deep level and help them bridge the confusing dimensions of the world. Folk stories and fairy tales of other cultures teach children to embrace the uniqueness of different societies. Stories can be narratives, but narratives, are not necessarily all stories, as narratives may also be more plot based or information based account that leave the connections of context, meaning and the relevance to the reader. As human activities become more refined and complex, visual stories are presented in images, carved into wood, ivory or stone or painted on canvas and stored electronically as digital images.

Story telling is the act of giving account of past events or of how something has developed. It is also the art of using language, vocalization and/or physical movement and gesture to reveal the elements and images of a story to a specific live audience (Chung, 2007).). Moreover, the National Storytelling Network (USA) establishes that storytelling is interactive, and that the responses of the listeners influence the telling of the story. Story telling emerges from the interaction/cooperative and co-ordinated efforts of the teller and the audience. Using stories in the classroom has been found to be of great importance to the growth of children in their educational pursuit. The use of oral histories in the classroom is a very important tool in student growth. When children listen to stories, their imaginations are enriched and stimulated.

Today, classroom teaching and learning is enhanced with technology. Curriculum concept are transformed into stories and supported with technologies in multimedia tools and embedded in learning channels of visual, auditory and kinaesthetic formats. Adding such aids makes a story become more mediated and 
digitalized through which it becomes richer in content and application. The action referred as to the delivery of the story is known as "Digital Storytelling".

Contemporary technologies in education revolve round the use of computers. Computer as used in this study is a machine that can help with many different teaching and learning tasks when it is integrated into classroom activities. The most important aspect of computers in education is that they provide drill and practice for the student. Teacher's activities may be tedious at times and computers provide motivation to the student to continue learning (Dogan, 2011). Teachers are not to be limited to the use of computer technology or understanding a computer tool. It requires knowledge of the learner, the content to be learned, as well as an understanding of how computer tools can be used to help the learners accomplish learning goals. Human beings use tools to make lives better. In education, technologies are used in teaching and learning process. Farmer, (2004) affirms that technology makes learning easy, effective and permanent. It provides children with needed information through the computer and other technological teaching and learning materials. Children have access to manipulate information at a rapid speed or rate. They equally discover creative ways of learning.

Digital Storytelling is a modern expression of the ancient art of storytelling (Kajder,. and Swenson, 2004).). Throughout history, storytelling is used to share knowledge, wisdom and values. Stories are adapted to each successive medium that emerged, from the circle of the campfire to the silver screen, and now computer screen. Digital stories use narrative and voice together, thereby giving deep dimension and vivid colour to characters, situations, experiences and insights. Digital storytelling is a term used across disciplines, from education to entertainment and the definitions and descriptions vary just as widely. Digital storytelling has been defined by many proponents as a process of creating short stories that allow students and educators to enhance their information gathering and problem-solving skills, and to facilitate the ability to work in a collaborative team; a narrative told in digital format that shares a point of view, after the tellers' point of view, a personalised multimedia tales told from the heart and "the practice of using computer-based tools to tell stories" (Robin (2009), As with traditional storytelling, most digital stories focus on a specific topic and contain a particular point of view.

The popularity of digital storytelling has increased in the last two decades. It is used around the world (Yuksel, Robin and McNeil, 2011). Meadows believed that, the use of digital storytelling around the world is done to the relatively low cost of digital devices, the ease of learning to create digital stories, and the availability of many sites on the web where stories may be displayed and shared. Robin (2011), has classified digital storytelling into three categories - personal narratives, stories that examine historical events and stories that are primarily used to inform or instruct. It is little wonder that digital storytelling is being used in various fields

With technology, storytelling has evolved in different formats, such as visual storytelling, using images and text to create visual stories and digital storytelling (Robin,2009). The prevalent storytelling in the digital era refers to using computer-based tools to tell stories (Robin, 2011). In contrast to using technology as a tutor or practice partner, digital storytelling utilizes technology as a means for students to demonstrate their understanding, empowering learners in engaging and authentic ways.

The use of digital storytelling has been proven to be a powerful and effective learning tool for both teachers and students in stimulating creativity and critical thinking through the combination of the ancient art of telling stories with different digital tools. The process of creating digital story in the classroom provides exploratory hands-on-learning, collaborative social interaction, experiential learned activities and active roleplay that go beyond the traditional classroom setting.

Studies pointed to differences in the way students responded to the use of digital story-telling in the classroom. Findings from Ya-Ting, Yang,\& Wan-Chi (2012):) on the digital story-telling relevant to teaching and learning show that, digital story-telling in the Arts, Humanities and Social Sciences provide rich opportunities for self-reflection. He also sees it as a tool for students to compare their "stories" with those authored by people from other culture and other life experiences. Ohler, (2006), has pointed out from his pedagogical perspective that producing humorous video-based digital story could be used to improve student's language skills. So also, integration of humorous element or parody in the digital story could enhance learner's creativity and critical thinking.

From a classroom teaching perspective, digital storytelling can be an accessible and productive use of educational technology because it utilizes technology that is increasingly affordable and fairly simple to learn, and combines the technology with storytelling and story writing skills, these are skills that teachers teach as part of the regular curriculum. In the present day teacher training programme in Nigeria, the teacher is essentially trained to impart instruction within the frame-work of curricular content, supported by textbook materials. This type of teaching methodology promotes passive learning as students may not fully understand contents of the topic. In this regard, digital storytelling can be used as an effective technique to promote students' learning and creativity especially at Primary School level.

According to Dogan, B. \& Robin,(2011) Digital storytelling plays a major role in the education of today's students because it "utilizes almost all of the skills students are expected to have in the $21{ }^{\text {st }}$ century. 
Dogan, B. \& Robin,(2009) believed that through the creation of creative stories and the use of digital media, students will enhance their "digital, global, technology, visual, and information literacies." Robin(2011) further, research, writing, organization, technology, presentation, interview, interpersonal, problem-solving, and assessment skills" will be improved as well through the process of creating their stories and producing their own digital story.

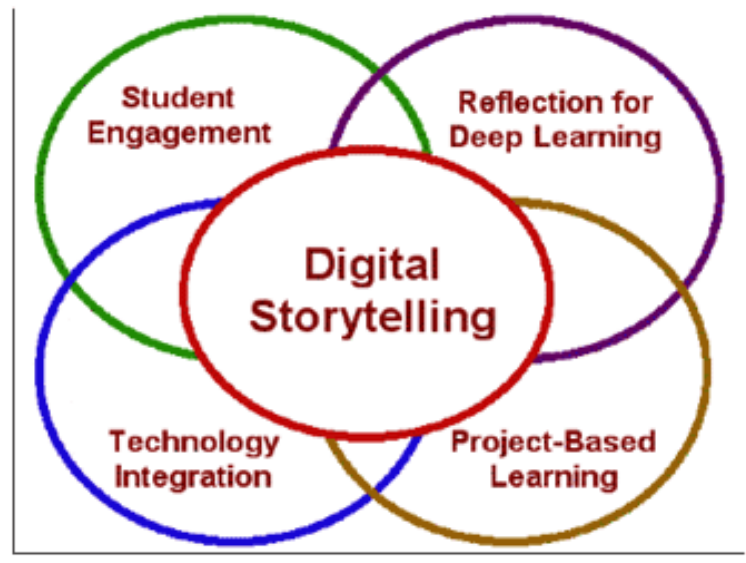

Figure 1: the intersection of four student-centered learning in Digital storytelling Source: Yuskel, Robin, and McNeil, ( 2011)

In the classroom, digital storytelling is at the intersection of four student-centered learning strategies). Barrett, (2005) It is also "appealing to students with diverse learning styles.(Robin ,2011)

Although there has not been a great deal of research conducted thus far on the use of digital media in the classroom, the studies that have been conducted have yielded certain benefits that come from using digital storytelling. These benefits include supporting "student understanding of subject area knowledge," increasing "overall academic achievement," and improving "higher order thinking, social, language, reflection, and artistic skills. ( Yuskel, Robin, and McNeil,2011)

Since digital storytelling is often performed in small groups, student collaboration within the classroom is fostered.(Robin, 2011) In collaborative environments, it has also been found that students "develop enhanced communications skills by learning to organize their ideas, ask questions, express opinions, analyze and synthesize a wide range of content, and construct narratives. ( Ibid, 2009) Within Digital storytelling, pupils will also be able to "share their work with peers and gain valuable experience in critiquing their own and other students' work.” ( Ibid, 2009)

Despite the many benefits found from using digital storytelling in the classroom, research has also shown that there are certain limitations that educators have encountered when attempting to incorporate digital storytelling into their curriculum. One of the most widely stated limitations is time; some educators found that digital storytelling takes away from class time that could be used for teaching to the standardized state testing.(Dogan ,2011) Digital storytelling seeks to address this particular issue by creating curriculum- driven opportunities that correlate to the need to teach to standardized tests.

Further, the issue of copyright is one that has plagued educators for quite some time and digital storytelling can exacerbate this issue. (Robin, 2011) Thankfully, there are now websites that allow students access to free music and artwork that they can incorporate into the projects with correct citation. ( Ibid.2009) Additionally, Digital storytelling offers its own supporting documentation to help students avoid situations that border on copyright infringement.

Teaching and learning processes in the primary schools are mostly done through rote learning and memorization. However, teaching Moral should be with excitement, using enjoyable stories and not just sitting still for endless periods of time. The kids need to be involved in the teaching-learning activities; so that the teaching of the subject would spur them to have a deep reflection on the learning experience they are being exposed to. This will result in effective, meaningful and enjoyable learning. The kids would then be able to imbibe the morals given to them by their teachers, for character is far more important than knowledge knowledge is only a means to an end, that end being the living of a useful and honourable life.

Osokoya, (2006) found that, in the Nigerian Primary schools, girls were given less time to tasks than boys which no doubt hindered the performances of the female and girl-child and (Chamber 2009) concluded in his research that, gender based education can affect standardized test score for both positive and negative outcomes.. 


\section{Statement of the Problem}

Recent developments in classroom activities of teaching and learning encourage methodologies that reflect learners' active participation, interactive patterns and inclusive learning. With the use of technology, teachers take kids beyond traditional classroom limit, ensure adequate participation in teaching and learning process and create environment for experimentation and exploration. Again, there are doubts about the Moral Instruction taught in Nigerians Schools. Major stakeholders in Nigerian Education sector show concern about the morals and values among kids in primary school. Thus, the study will probe into the effectiveness of two digital story telling modes in Moral Instruction taught in Oyo State Primary Schools. Furthermore, it investigated the moderating effects of gender on kids' performances in Moral Instruction.

\section{Hypotheses}

The following hypotheses will be tested at 0.05 level of significance.

1. There is no significant effect of digital storytelling on pupils learning achievement in Moral Instruction.

2. There is no significant gender effect of treatment on pupils learning achievement in Moral Instruction.

\section{Methodology}

This study adopted pre-test, post-test, control group, quasi experimental design.

Participants for this study will comprise pupils from public primary schools from the Oyo state is stratified into three senatorial districts: Oyo North, Oyo Central and Oyo South. One senatorial district, Oyo North was randomly selected for the study. Out of the 33 Local Government Areas in Oyo State, three Local Government Areas will be randomly selected. These are Iseyin, Itesiwaju and Kajola Local Government Areas. Three schools will be purposively selected from each LGA. In each school, an intact class will be selected out of all the nine representative schools for the study.

based on the following criteria:

i Relative distance from one another to avoid contamination

Ii Government owned schools

iii Availability of qualified Pre-primary teachers teaching Moral instruction in kindergarten classes. These schools will be randomly assigned to experimental and control groups. Using simple random sampling,

\section{Research instruments}

Five research instruments were used in this study. These are:

1. Classroom Observation (CO)

2. Kindergaten Achievement Test on Moral Instruction

3. Digital story package

4. Teachers Guide on Digital Storytelling Strategy (TGDSS)

5. Teachers Guide on Conventional Strategy (TGCS).

\section{Classroom observation}

This is used to measure classroom processes which include specific teacher practices, holistic aspects of instructions and interactions between teachers and kids. Classroom observation is often regarded as a naturalistic method to observe those classroom practices of teachers that are affective or have positive impacts on certain kindergarten pupils outcomes. The scale to be used is adopted one from Consortium for Policy Research Education (1994).

\section{Kindergarten achievement test on Moral Instruction}

The pupils achievement test in Moral instruction was designed and constructed by the researcher to measure pupils level of achievement in selected Moral instruction concept based on the three levels of cognition, viz; remembering, understanding and thinking (Okpala, Unoche and Oyedeji, 1993).

The instrument consist of two- sections A and B. Section A; sought personal information of students while section B consists of 10 multiple choice questions with three options. For each question, one correct answer and two other distracters were provided.

Questions were drawn from the concept of Personal hygiene, Sanitation and Feeding habit. The instruments were given to expert in the fields of Childhood education, education evaluation and educational technology for corrections and suggestions before it was used.

It has two sections with Section (A) containing demographic information such as Name of School, Students Name, Class, Gender, Age while section B containing the test items constructed as presented in Table 3.2.The options for the questions ranges from A to C. One mark was awarded for each corrects option and zero for wrong option. This means that the total marks obtained is 25 . The test items were generated to cover the 
three lower cognitive domains of knowledge, comprehension and Understanding in accordance with Yoloye (1984). The table of specification is contained in table 1.

Table 1: Table of Specification for Moral Instruction)

\begin{tabular}{|l|l|l|l|l|}
\hline Topic & Knowledge & Comprehension & Understanding & Total \\
\hline Personal hygiene & $(1) 1$, & $(1) 4$ & $(1) 3$ & 3 \\
\hline Sanitation & $(1) 6$, & $(1) 7$ & $(1) 10$ & 3 \\
\hline Feeding habit & $(2) 5,8$ & $(1) 2$ & $(1) 9$ & 4 \\
\hline Total & 4 & 3 & 3 & 10 \\
\hline
\end{tabular}

Validation and Determination of Reliability coefficient Kindergarten Achievement test

The initial draft of thirty multiple choice items were given to some lecturers in Early childhood Unit of the Department of Teacher Education, Faculty of Education, University of Ibadan, Ibadan; some Ph.D students in the field of Childhood education. This was done to ascertain the face, content and construct validity of the instrument. The thirty (30) multiple choice items were reduced to twenty (20) items while fifteen (15) items survive scrutiny which fell within the discriminating indices of 0.4 to 0.6 . It was later trial-tested in a representative lower Basic school that was not part of the study. The data collected were analyzed using KuderRichardson formula 20 (KR20). The reliability coefficient of 0.81 and an average item difficulty index of 0.49 were obtained.

\section{Digital Story telling Package}

The validation was carried out in line with the stipulated process of validating instructional package in educational technology which include content validation, computer expert validation, educational technology validation, one-to-one validation, small group validation and field trial validation.

\begin{tabular}{|c|c|c|c|c|}
\hline CATEGORY & Excellent & Good & Satisfactory & Needs Improvement \\
\hline $\begin{array}{l}\text { Point of View- } \\
\text { purpose }\end{array}$ & $\begin{array}{l}\text { Establishes a purpose early } \\
\text { on and maintains a clear } \\
\text { focus throughout. }\end{array}$ & $\begin{array}{l}\text { Establishes a purpose } \\
\text { early on and maintains } \\
\text { focus for most of the } \\
\text { presentation. }\end{array}$ & $\begin{array}{l}\text { There are a few lapses in } \\
\text { focus, but the purpose is } \\
\text { fairly clear. }\end{array}$ & $\begin{array}{l}\text { It is difficult to figure } \\
\text { out the purpose of the } \\
\text { presentation }\end{array}$ \\
\hline $\begin{array}{l}\text { Point of View - } \\
\text { Awareness of } \\
\text { Audience }\end{array}$ & $\begin{array}{l}\text { Strong awareness of } \\
\text { audience in the design. } \\
\text { Pupils can clearly explain } \\
\text { why they felt the } \\
\text { vocabulary, audio and } \\
\text { graphics chosen fit the } \\
\text { target audience }\end{array}$ & $\begin{array}{l}\text { Some awareness of } \\
\text { audience in the design. } \\
\text { Pupils can partially } \\
\text { explain why they felt } \\
\text { the vocabulary, audio } \\
\text { and graphics chosen fit } \\
\text { the target audience. }\end{array}$ & $\begin{array}{l}\text { Some awareness of } \\
\text { audience in the design. } \\
\text { Pupils find it difficult to } \\
\text { explain how the } \\
\text { vocabulary, audio and } \\
\text { graphics chosen fit the } \\
\text { target audience }\end{array}$ & $\begin{array}{l}\text { Limited awareness of } \\
\text { the needs and interests } \\
\text { of the target audience. }\end{array}$ \\
\hline $\begin{array}{l}\text { Dramatic } \\
\text { Question }\end{array}$ & $\begin{array}{l}\text { Realization is dramatically } \\
\text { differ from expectation }\end{array}$ & $\begin{array}{lr}\text { Realization } & \text { differs } \\
\text { noticeably } & \text { from } \\
\text { expectation } & \\
\end{array}$ & $\begin{array}{l}\text { Realization barely differs } \\
\text { from the expectation. }\end{array}$ & $\begin{array}{lll}\text { Realization } & & \text { and } \\
\text { expectation do } & \text { not } \\
\text { differ } & & \\
\end{array}$ \\
\hline $\begin{array}{l}\text { Voice- } \\
\text { Consistency }\end{array}$ & $\begin{array}{l}\text { Voice quality is clear and } \\
\text { consistently audible } \\
\text { throughout } \\
\text { presentation. }\end{array}$ & $\begin{array}{l}\text { Voice quality is clear } \\
\text { and consistently audible } \\
\text { throughout the majority } \\
(x 5-95 \%) \text { of the } \\
\text { presentation }\end{array}$ & $\begin{array}{l}\text { Voice quality is not clear } \\
\text { and consistently audible } \\
\text { through presentation. }\end{array}$ & $\begin{array}{l}\text { Voice quality needs } \\
\text { more attention. }\end{array}$ \\
\hline $\begin{array}{l}\text { Voice- } \\
\text { Conversational } \\
\text { Style }\end{array}$ & $\begin{array}{l}\text { Uses a conversational style } \\
\text { throughout }\end{array}$ & $\begin{array}{l}\text { Uses a conversational } \\
\text { style the majority (85- } \\
95 \%) \text { of the time }\end{array}$ & $\begin{array}{l}\text { Uses a conversational } \\
\text { style most }(70-84 \%) \text { of } \\
\text { the presentation. }\end{array}$ & $\begin{array}{l}\text { Presentation style is } \\
\text { primarily monologue. }\end{array}$ \\
\hline Voice-Pacing & $\begin{array}{l}\text { The pace (rhythm and } \\
\text { voice punctuation) fits the } \\
\text { story line and helps the } \\
\text { audience really "get into" } \\
\text { the story. }\end{array}$ & $\begin{array}{l}\text { Occasionally speaks too } \\
\text { fast or too slowly for the } \\
\text { story line. The pacing } \\
\text { (rhythm and voice } \\
\text { punctuation) is } \\
\text { relatively engaging for } \\
\text { the audience. }\end{array}$ & $\begin{array}{l}\text { Tries to use pacing } \\
\text { (rhythm and voice } \\
\text { punctuation), but it is } \\
\text { often noticeable that the } \\
\text { pacing does not fit the } \\
\text { story line. Audience is } \\
\text { not consistently engaged. }\end{array}$ & $\begin{array}{l}\text { No attempt to match } \\
\text { the pace of the } \\
\text { storytelling to the story } \\
\text { line or the audience. }\end{array}$ \\
\hline $\begin{array}{l}\text { Soundtrack- } \\
\text { Originality }\end{array}$ & All of the music is original & $\begin{array}{l}\text { Most (over half) of the } \\
\text { music is original. }\end{array}$ & $\begin{array}{l}\text { Some of the music is } \\
\text { original. }\end{array}$ & $\begin{array}{l}\text { None of the music is } \\
\text { original. }\end{array}$ \\
\hline $\begin{array}{l}\text { Soundtrack- } \\
\text { Emotion }\end{array}$ & $\begin{array}{l}\text { Music stirs a rich } \\
\text { emotional response that } \\
\text { matches the story line well. }\end{array}$ & $\begin{array}{l}\text { Music stirs a rich } \\
\text { emotional response that } \\
\text { somewhat matches the } \\
\text { story line. }\end{array}$ & $\begin{array}{l}\text { Music is ok, and not } \\
\text { distracting, but it does not } \\
\text { add much to the story. }\end{array}$ & $\begin{array}{l}\text { Music is distracting, } \\
\text { inappropriate, OR was } \\
\text { not used. }\end{array}$ \\
\hline Images & $\begin{array}{l}\text { Images create a distinct } \\
\text { atmosphere or tone that } \\
\text { matches different parts of } \\
\text { the story. The images may } \\
\text { communicate symbolism } \\
\text { and/or metaphors. }\end{array}$ & $\begin{array}{l}\text { Images create an } \\
\text { atmosphere or tone that } \\
\text { matches some parts of } \\
\text { the story. The images } \\
\text { may communicate } \\
\text { symbolism and/or }\end{array}$ & $\begin{array}{l}\text { An attempt was made to } \\
\text { use images to create an } \\
\text { atmosphere/tone but it } \\
\text { needed more work. Image } \\
\text { choice is logical }\end{array}$ & $\begin{array}{l}\text { Little or no attempt to } \\
\text { use images to create an } \\
\text { appropriate } \\
\text { atmosphere/tone }\end{array}$ \\
\hline
\end{tabular}


The Effect of Digital Storytelling on Kindergarten Pupils' Achievement in Moral Instruction in....

\begin{tabular}{|c|c|c|c|c|}
\hline & & metaphors. & & \\
\hline Economy & $\begin{array}{l}\text { The story is told with } \\
\text { exactly the right amount of } \\
\text { detail throughout. It does } \\
\text { not seem too short nor } \\
\text { does it seem too long. }\end{array}$ & $\begin{array}{l}\text { The story composition } \\
\text { is typically good, } \\
\text { though it seems to drag } \\
\text { somewhat OR need } \\
\text { slightly more detail in } \\
\text { one or two section. }\end{array}$ & $\begin{array}{l}\text { The story seems to need } \\
\text { more editing. It is } \\
\text { noticeably too long or too } \\
\text { short in more than one } \\
\text { section. }\end{array}$ & $\begin{array}{l}\text { The story need } \\
\text { extensive editing. It is } \\
\text { too long or too short to } \\
\text { be interesting. }\end{array}$ \\
\hline $\begin{array}{ll}\text { Duration } & \text { of } \\
\text { Presentation } & \end{array}$ & $\begin{array}{l}\text { Length of presentation was } \\
4 \text { minutes. }\end{array}$ & $\begin{array}{l}\text { Length of presentation } \\
\text { was } 3 \text { minutes. }\end{array}$ & $\begin{array}{l}\text { Length of presentation } \\
\text { was } 2 \text { minutes. }\end{array}$ & $\begin{array}{l}\text { Presentation was less } \\
\text { than } 2 \text { minutes long } \\
\text { OR more than } 4 \\
\text { minutes. }\end{array}$ \\
\hline
\end{tabular}

Digital Storytelling Rubric (Based on several rubrics posted online at: http:llrubistar,Ateachers,org)

The instrument was subjected to reliability test using Cronbach alpha and a reliability coefficient of 0.82 was obtained.

\section{Teachers' guide for Digital Storytelling strategy}

This instrument was designed to guide the teachers in the experimental group on their expected role premised on the design of the study as a self-learning package thereby limiting the role of the teacher to that of moderator. The role of the teacher was limited to making preparation for the use of the Digital machine, allotting the learners to sit conveniently and monitoring the kids to ensure that they pay attention to the package. The operational guideline was given to experienced Pre-primary teachers and Childhood education lecturers for face and content validity. Their observations and suggestions were taken into consideration to improve the quality of the instrument.

\section{Operational Guideline for Conventional Group (OGCG)}

This instrument was designed to guide the teachers in the control group. The lesson note on each topic was prepared by the researcher with focus on the behavioural objectives, presentation of content with the use of relevant instructional materials prepared by the researcher based on the same information incorporated in the package for the experimental group, and evaluation. The guide was also given to experienced Pre-primary teachers and lecturers for face and content validity. Observations and suggestions made were incorporated to improve the quality of the instrument.

\section{Research Procedure}

The researcher made use of the regular subject teachers in administering the treatment. The treatment took 14 weeks as stated below:

Table 2: Research Procedure

\begin{tabular}{|l|l|l|l|}
\hline S/N & WEEK & ACTIVITIES & TOPIC \\
\hline 1. & $1^{\text {st }}$ Week & $\begin{array}{l}\text { (i) Took permission from the school } \\
\text { authority } \\
\text { (ii) Selected and trained the research } \\
\text { assistants (Pre-primary Teacher) }\end{array}$ & \\
\hline 2. & $2^{\text {nd }}$ Week & $\begin{array}{l}\text { (i) Conducted pre-test for both experimental } \\
\text { and control group }\end{array}$ & $\begin{array}{l}\text { Personal Hygiene, Sanitation and } \\
\text { Feeding Habit }\end{array}$ \\
\hline 3. & $3^{\text {rd }}-10^{\text {th }}$ Week & Commenced treatment for both groups & $\begin{array}{l}\text { Personal Hygiene, Sanitation and } \\
\text { Feeding Habit }\end{array}$ \\
\hline 4. & $11^{\text {th }}$ Week & Conducted post test for both groups & $\begin{array}{l}\text { Personal Hygiene, Sanitation and } \\
\text { Feeding Habit }\end{array}$ \\
\hline
\end{tabular}

\section{Training of Teachers}

The first week was used to train the research assistants (Pre-primary teachers in the schools for the study). The researcher explained the purpose and procedure for the study to them. The teachers in the experimental group were exposed to the use of the instructional package by the researcher after which they were allowed to use it in order to assess their competence.

The teachers in the control group were also familiarised with the purpose and procedure for the study. The objectives and content of each topic was given to each of them.

\section{Pre-test}

After the training of the teachers, the administration of Kindergarten Achievement Test was done in each group: 


\section{Treatment}

The participating teachers carried out the treatments in both groups for a period of eight weeks. However, the researcher went round the schools once a week to ascertain compliance with the operational guideline.

\section{Steps followed in the experimental group}

The kids:

(i) were allotted the Digital machine by the teacher.

(ii) opened the package with the supervision of research assistant,

(iii) Listen and watch the stories on the Digital machine.

(iv) The teacher moved round the classroom to monitor the kids.

(v) asked questions from the students,

(vi) summarised the lesson and

(vii) gave assignment.

(viii) The teacher made sure that the kids did not spoil the machines before, during and when the lesson period was over.

\section{Steps followed in the control group:}

The teacher:

(i) wrote the topic for the lesson on the chalkboard,

(ii) stated the objectives for the lesson,

(iii) outlined the content of the topic on the chalkboard,

(iv) explained the content by making use of the information provided by the researcher in handling each of the topics

(v) asked questions from the students,

(vi) summarised the lesson and

(vii) gave assignment.

\section{Post test}

This was administered in the eleventh week. The achievement test was administered.

\section{Data Analysis}

Analysis of Covariance (ANCOVA) of inferential statistics was used in testing the hypotheses using the pre-test scores as covariates and Estimated Marginal Mean was computed to show how the groups performed. All hypotheses were tested at 0.05 level of significance.

\section{Results}

Table 3: Summary of ANCOVA of Post test Achievement between Treatment group and Gender

\begin{tabular}{|l|l|l|l|l|l|l|}
\hline Source & Sum of Squares & DF & Mean Square & F & Sig. & $\begin{array}{l}\text { Eta } \\
\text { Square }\end{array}$ \\
\hline Main Effect: & 6033.809 & 18 & 335.212 & 10.910 & .000 & .347 \\
Pre-test (Achievement) & 1198.833 & 1 & 1198.833 & 39.019 & .000 & .095 \\
Treatment groups & 1806.420 & 2 & 903.210 & 29.397 & .000 & .137 \\
Gender & 44.636 & 1 & 44.636 & 1.453 & .229 & .004 \\
Explained & 6033.809 & 18 & 335.212 & & & \\
Residual & 55249.000 & 370 & 30.724 & & & \\
Total & 17401.779 & 388 & & & & \\
\hline
\end{tabular}

Ho 1: There is no significant main effect of treatment on pupils' Achievement in Moral Instruction from table 3 , it is shown that there is a significant main effect of Treatment groups on students' Achievement in Moral Instruction. $(\mathrm{F}(2,385)=29.397, \mathrm{P}<.05)$. The null hypothesis is rejected;

Table 4: Estimated Marginal Means of Treatment on Students' Achievement in Moral instruction

\begin{tabular}{|l|l|l|l|l|l|}
\hline Treatment & $\mathbf{N}$ & Mean & Std. Error & \multicolumn{2}{|c|}{ 95\% confidence interval } \\
\cline { 5 - 7 } & & & & Lower Bound & Upper Bound \\
\hline Experimental & 199 & 9.730 & 2.35 & 9.760 & 9.700 \\
\hline Control & 188 & $4 . .293$ & 1.44 & 4.290 & 4.296 \\
& & & & & \\
\hline
\end{tabular}

Table 4 shows that pupils in the Digital storytelling group had higher adjusted post-test achievement ( $\bar{x}=9.73)$,with the control group trailing behind $(\bar{x}=4.293)$. 
The Effect of Digital Storytelling on Kindergarten Pupils' Achievement in Moral Instruction in....

Ho 2: There is no significant main effect of Gender on pupils' Achievement in Moral Instruction. From table 3 , it is shown that there is no significant main effect of Gender on students' Achievement in Moral Instruction. $(\mathrm{F}(1,386)=1.453, \mathrm{P}>.05)$. The null hypothesis is not rejected.

Table 5: Estimated Marginal Means of Gender on Students' Achievement in Moral instruction

\begin{tabular}{|l|l|l|l|l|l|}
\hline Gender & $\mathbf{N}$ & Mean & Standard Error & \multicolumn{2}{|l|}{ 95\% confidence interval } \\
\cline { 5 - 6 } & & & & Lower Bound & Upper Bound \\
\hline Female & 76 & 9.690 & 1.46 & 9.610 & 9.770 \\
\hline Male & 107 & 9.740 & 1.43 & 8.740 & 10.740 \\
\hline
\end{tabular}

Table 3 shows that male pupils in the Digital storytelling group had higher adjusted post test achievement $(\bar{x}$ $=9.740)$, with the male trailing behind $(\bar{x}=9.690)$.

\section{Discussion}

From table 3 it is shown that there is a significant main effect of Treatment groups on pupils' Achievement in Moral Instruction. Digital storytelling allows pupils to share their stories outside of the traditional written form. According to Robin, (2011), it allows pupils to develop creative presentations utilizing a number of different skills, including writing, performance, and technological skills. In addition, digital storytelling provides an opportunity for collaboration and cooperation among teachers and librarians. Studies suggest that both digital storytelling and librarian-teacher collaboration has an impact on pupils' achievement.

Farmer (2004) argues that digital storytelling is not as simple as it may at first sound. She asserts that "for pupils to succeed in this Endeavour, they must know their facts, make decisions about the key elements, and shape those within the parameters of telling a story. Such work involves high-level information literacy, critical thinking and creativity; the result is an original and authentic product of the child's knowledge and imagination.

According to Dogan, (2011), Digital storytelling incorporates art, drama, writing, reading, and technology skills. While primarily described in terms of the language arts curriculum, digital storytelling can be used to illustrate problem solving in Numeracy or to tell the story of cleaningness, or simply to tell a story in kids' language to develop fluency. Working in conjunction with school library media specialists, art teachers, and another subject teacher, pupils learn to translate a story into a visual medium. In an Art Education article Chung (2007) argues that "digital storytelling provides pupils with a stimulating aesthetic means of developing critical-thinking and problem solving skills, and of cultivating aesthetic sensitivities. Not only does digital storytelling allow pupils to express themselves visually, it also addresses skills relevant in other subjects

\section{Educational Implications}

The exposures of the learners to Digital storytelling strategy have been found to positively affect the pupils' achievement in moral instruction. The findings have showed the importance of using teaching strategies that are participatory and pupils' centre where their attentions are excited leading to improvement in achievement.

Stories provide entertainment and convey information that educates kids on moral issues and values that endure and benefit generations of different societies.

Digital storytelling handed down to kids the experiences, exploits, customs, traditions and cultures through stories that are considered before making decisions.

\section{Recommendation}

Based on the results and discussion, the following recommendations are advanced

While teachers may undertake a digital storytelling lesson on their own, they are more likely to tackle such a project in conjunction with another educator, particularly if they feel intimidated by the technology. Since digital storytelling can be utilized across all subject fields, it is an important and useful tool that school library media specialists can offer to teachers as a collaborative project.

(1) Digital storytelling strategy should be adapted as viable strategy for studying concepts in kindergarten classes. This will enable pupils improve on achievement in moral instruction.

(2) The Pre-primary teacher training curriculum at all levels of education should be upgraded to education relating to the real life situation by incorporating (i.e. activity innovative pedagogical strategy base instructional strategy such as Digital storytelling strategy).

(3) Teaching strategies Digital storytelling strategy learning that reduce the gender difference in kindergarten classes as recorded in this research work could be used to reduce learning anxiety for both sex (male and female) kids.

(4) Government and other employers of labour should ensure that qualified and competent Pre-primary teachers are engaged for teaching Moral instruction in lower basic schools.. 


\section{References}

[1]. Barrett, Helen. (2005) "Researching and Evaluating Digital Storytelling as a Deep Learning Tool" Retrieved August 1, 2011 from http://electronicportfolios.com/portfolios/SITEStorytelling2006.pdf

[2]. Buzzeo, T. (2002). Collaborating to Meet Standards: Teacher/Librarian Partnerships for K-6. Worthington, OH: Linworth Publishing Inc.

[3]. Chung, S. K. (March 2007). Art Education Technology: Digital Storytelling [Electronic version]. Art Education, 60(2), 17-22.

[4]. Dogan, B. "Educational Uses of Digital Storytelling: The Challenges of Designing an Online Digital Storytelling Contest for K-12 Students and Teachers" Retrieved August 1, 2011.

[5]. Dogan, B. \& Robin, B. (2009). "Educational Uses of Digital Storytelling: Creating Digital Storytelling Contests for K-12 Students and Teachers." In I. Gibson et al. (Eds.), Proceedings of Society for Information Technology \& Teacher Education International Conference 2009 (pp. 633-638). Chesapeake, VA: AACE. Retrieved fromhttp://www.editlib.org/p/30673.

[6]. Dogan, B. \& Robin, B. (2009). "Implementation of Digital Storytelling in the Classroom by Teachers Trained in a Digital Storytelling Workshop" University of Houston, Educational Uses of Digital Storytelling. Retrieved August 1, 2011 fromhttp://digitalstorytelling.coe.uh.edu/pdfs/Dogan-DS-Research-2008.pdf

[7]. Farmer, L. (2004). Using Technology for Digital Storytelling: Tools for Children [Electronic version]. New Review of Children's Literature and Librarianship, 10(2), 155-168. Ibid.; S. Friesen,(2009) "Galileo Educational Network: Creating, Researching and Supporting 21st Century Learning," Education Canada 49, no. 5 (2009): 7-9.

[8]. Kajder, S. and Swenson, J.A. (May 2004). Digital Images in the Language Arts Classroom [Electronic version]. Learning and Leading with Technology, 31(8), 18-19, 21, 46.

[9]. Kajder, S.B. (2006). Bringing the Outside In: Visual Ways to Engage Reluctant Readers. Portland, ME: Stenhouse Publishers.

[10]. Maier, Robert Brick and Mercedes Fisher. (2006-2007). Strategies for Digital Storytelling via Tabletop Video: Building Decision Making Skills in Middle School Students in Marginalized Communities. Journal of Educational Technology Systems, 35(2), 175192.

[11]. National Council of Teachers of English. (November 2005). Multimodal Literacies. Retrieved November 7, 2007, from http://www.ncte.org/about/over/positions/category/media/123213.htm

[12]. Ohler, Jason. (December 2005/January 2006). The World of Digital Storytelling [Electronic version]. Educational Leadership, 63(4), 44-47.

[13]. Osokoya, M.M. 2006 Moden Trends in the Teaching of Secondary Schools Chemistry in Ayodele S. O. (ed) Teaching Strategies for Nigerian Secondary Schools pp. 213-229.

[14]. Robin, B. (2009). "The Educational Uses of Digital Storytelling: Retrieved on August 1, 2011 from http://faculty.coe.uh.edu/brobin/homepage/Educational-Uses- DS.pdf

[15]. Robin, B. (2009). "The Educational Uses of Digital Storytelling: Retrieved on August 1, 2011 from http://faculty.coe.uh.edu/brobin/homepage/Educational-Uses- DS.pdf

[16]. Robin, B. (2009). "The Educational Uses of Digital Storytelling: Retrieved on August 1, 2011 from http://faculty.coe.uh.edu/brobin/homepage/Educational-Uses- DS.pdf

[17]. Robin, B. (2009). "The Educational Uses of Digital Storytelling: Retrieved on August 1, 2011 from http://faculty.coe.uh.edu/brobin/homepage/Educational-Uses- DS.pdf

[18]. Ya-Ting C. Yang, Wan-Chi I. Wu (2012): Digital Storytelling for Enhancing Student Academic Achievement, Critical Thinking, and Learning Motivation: A Year-long Experimental Study

[19]. Yoloye, E. (1984). "The role of the home and school in helping the Individual towards self-realization and maximization of his or her potentials. Journals of the Nigerian Careers Council, 3,1. pp. 20-21.

[20]. Yuskel, P., Robin, B. and McNeil, S. "Educational Uses of Digital Storytelling Around the World" Retrieved August 1, 2011 from http://digitalstorytelling.coe.uh.edu/survey/SITE DigitalStorytelling.pdf 